\title{
PALACIANOS E AULICISMO NO SEGUNDO REINADO - a facção áulica de aURELIANO coUtinho e OS BASTIDORES DA CORTE DE D. PEDRO II.
}

\author{
Julio Bentivoglio
}

Resumo: Discute-se aqui o significado do aulicismo e a presença da nobreza palaciana na vida política imperial brasileira entre 1831 e 1848. Destaque para a chamada facção áulica de Aureliano Coutinho. São apontadas algumas características do grupo, sua inserção nos gabinetes e sua presença marcante governo e na política imperial oitocentista.

Palavras-chave: História Política; Brasil Império; Palacianos; Facção Áulica; Corte.

Aulicism and palatians in Second Empire - Aureliano Coutinho's facção áulica and the scenes of the court of D. Pedro II.

\begin{abstract}
This article discusses the significance of aulicism and the presence of the nobility palace in the imperial Brazil politics life between 1831 and 1848 . Highlight of the Aureliano Coutinho's facção áulica. Some caracteristics of the group are indicated, its inclusion in offices and its strong presence in government and imperial policy nineteenth.
\end{abstract}

Keywords: Political History; Brazil Empire; Palacians; Facção Áulica; Court.

\section{INTRODUÇÃO}

Referindo-se ao aulicismo na corte de D. Pedro II, Sérgio Buarque de Holanda vaticinou que a política no início do Segundo Reinado foi marcada por uma intensa disputa entre palacianos e partidaristas, na qual o espírito partidário derrotou aos poucos o aulicismo ${ }^{2}$. Talvez o célebre historiador paulista tenha sido

I Professor do Departamento de História Programa de Pós-Graduação em História Social das Relações Políticas da Universidade Federal do Espírito Santo. Email: juliobentivoglio@gmail.com. Esta pesquisa contou com apoio financeiro do CNPq. 
influenciado pela interpretação saquarema do conservador mineiro Firmino Rodrigues Silva ${ }^{3}$, mas o fato é que seu diagnóstico mostra-se bastante eficaz para compreender a política de então, que lentamente deixa de ser assunto de bastidores para se constituir em uma verdadeira política de partidos. Mas este processo de longa duração conviveu, entre 1808 e 1848, com a sombra e a influência permanentes da ação de validos atuando nos meandros da vida política imperial, enquanto se formavam as duas principais legendas partidárias do período.

Ainda está para ser escrita a história do valimento no Império brasileiro. Embora existam algumas obras de caráter mais geral e descritivo ${ }^{4}$, não houve, por parte da historiografia recente, o interesse em se analisar a vida e o quotidiano dentro da corte ao longo do século XIX - um centro de poder e de decisão , particularmente daqueles indivíduos que detinham o privilégio de compartilhar do dia-a-dia no Palácio de São Cristóvão, integrando a nobreza palaciana. O valimento é um fenômeno político imprescindível para se conhecer a elite e as relações de poder no Brasil durante o oitocentos, algo que até agora pouco interessou à historiografia. Segundo Ricardo de Oliveira,

no âmbito da cultura política do Antigo Regime, perceber que a problemática dos afetos e das relações de amizade, como elementos inerentes aos códigos culturais daquela sociedade, possuía sentidos e dimensões específicas (...) [e] a possibilidade ou não de ter acesso direto ao núcleo do poder ou mesmo de se ter êxito na tentativa de alcançar certa mobilidade social ascensional derivava, em larga medida, da qualidade das relações que cada aspirante possuía. Nessa sociedade, a lógica e o princípio do mérito pouco ou nada valiam, ser amigo de alguém poderoso e, mais do que tudo, ser amigo do rei tornava-se o elemento decisivo para qualquer trajetória social. O valido era, portanto, alguém que, através de lutas e disputas inerentes ao universo da corte, conseguia galgar posições e ocupar a centralidade do afeto régio, monopolizando o amor, a amizade e a graça 5 .

Foi na corte do rei James II na Inglaterra que os palacianos foram denominados áulicos e de lá o termo incorporou-se ao universo e ao vocabulário político no Império do Brasil ${ }^{6}$. Na linguagem política da época o conceito assumia uma conotação negativa, pois, áulico seria um súdito singular que vive sob a proteção e o patrocínio do monarca. Tanto no caso inglês quanto no brasileiro alguns desses palacianos podiam residir no próprio palácio do monarca. Em seu prenúncio durante o período joanino tais personagens e suas famílias foram inicialmente agraciados com as melhores casas, cedidas para abrigar a corte. Também mantiveram o direito de ocupar espaços dentro do Palácio imperial ${ }^{7}$, dando-se a impressão de que eram como que os olhos e os ouvidos do imperador. E na sociabi- 
lidade brasileira de então, estar sob o mesmo teto, assumia foros de ser da própria família.

Os conselheiros de Estado eram também chamados áulicos naquele tempo. Vez ou outra, na imprensa também era comum o uso desta alcunha para homens que pareciam ter a proteção de D. Pedro II. Para ser áulico era preciso ser palaciano, ou seja, ter valimento, título de nobreza e freqüentar a corte. Mas, a denúncia feita em 1847 de que Aureliano Coutinho de Oliveira liderava um grupo que agia nos bastidores do governo imperial manipulando D. Pedro II e interferindo na formação e dissolução dos gabinetes fez com que o termo áulico passasse a se referir exclusivamente ao grupo de Aureliano, ou seja, à facção áulica. A partir de então palaciano era quem vivia na corte, áulicos os integrantes da facção áulica e nobre era todo aquele detentor de título de nobreza. Todos os áulicos da facção eram palacianos, mas nem todos eram nobres e a alcunha teve seu teor pejorativo potencializado: eram vistos como interesseiros, aduladores e ambiciosos que se valiam da proximidade do monarca para angariar vantagens ${ }^{8}$, que se encarregavam de espalhar mexericos e que, invariavelmente, provocavam a instabilidade do regime ou levavam ao descrédito alguma reputação.

No exterior como no Brasil, a intimidade com a Coroa colocava os palacianos como mediadores no caminho de todo aquele que almejasse a simpatia do imperador e de sua família. E também que desejasse a nomeação para algum cargo, posto ou função, para si e para outrem nos quadros da administração imperial e ou provincial. Mediação quase sempre necessária, que tanto mais poderia ser facilitada, caso atingisse a benquerença dos homens que privavam do convívio junto à D. João VI, depois junto à D. Pedro I e, por fim, a D. Pedro II. Por isso, não poucos viam os palacianos como um grupo cuja interposição era repudiada. Para não se sujeitar a isto, alguns preferiam não auferir títulos nobiliárquicos, embora muitos daqueles que os possuíssem não fazer questão de freqüentar a corte ou de mimosear o imperador. Em alguns casos até se depreende uma viva atitude de desprezo aos rígidos protocolos do interior da nobreza por parte de algumas expressões políticas. Ao longo da história do Império não foi sem escândalo que muitos enxergavam o ritual do beija-mão, ou ainda censuravam os demasiados gastos com a manutenção da família imperial. A falta de pompa na corte de D. Pedro II pode ter exacerbado a imagem renitente na historiografia do caráter figurativo da corte e da nobreza brasileira.

\section{A NOBREZA DA TERRA E A CORTE}

Em livro recente, Maria Beatriz Nizza da Silva analisou o processo de nobilitação na colônia. Ela evidencia que no Brasil havia especificidades e que não ocorreu, como em Portugal um processo de reprodução social da nobreza. Aqui, 
como lá a nobilitação se fazia inicialmente pelo reconhecimento da linhagem, ou seja, colonos que vieram para o Brasil e eram descendentes de famílias nobres portuguesas. Mas havia também a retribuição por feitos militares, como no caso dos títulos concedidos por D. Pedro I após a independência àqueles que o auxiliaram mais diretamente. Para Nizza, as "formas mais visíveis dessa nobreza colonial ligavam-se à concessão do foro de fidalgo da casa Real, à atribuição de hábitos e mais raramente de comendas das três ordens militares (Cristo, Santiago e Avis)" ". Outra possibilidade era o reconhecimento de grandeza do peticionário, que comprovava por documentos e por ações o merecimento da distinção nobiliárquica. Mas, "ao contrário das habilitações para as ordens militares, onde só eram referidos os pais e os avós, nas justificações de nobreza elaboravam-se genealogias completas, remontando o mais longe possível no passado"10. Via de regra a concessão envolvia o conceito de mercê, fundamental para o Antigo Regime, pois identificava a benevolência e o amor do monarca pelos vassalos, "muito embora se detecte um substrato racional e mesmo uma avaliação quantitativa e qualitativa dos serviços prestados à Coroa" $"$.

Com a Independência, reconheceu Silvestre Pinheiro Ferreira era preciso combinar a nobreza hereditária com a de aquisição, ou seja, era imperativo fazer surgir das cinzas uma outra nobreza "mais conforme aos usos e costumes de nosso século"12. Este papel foi desempenhado, dentre outros, por Aureliano. Ele é um elo entre palacianos antigos e novos, do Primeiro e do Segundo Reinado, ao lado, por exemplo, do visconde e depois marquês de Olinda. Outro detalhe importante será a permanência de um número expressivo de nascidos em Portugal agraciados com títulos por D. Pedro I, bem maior que o de brasileiros. Ao lado de militares também eram agraciados muitos homens opulentos da terra. Na Tabela 1 (ver anexo) estão localizadas as mercês conferidas pelos titulares do governo. Nela pode se ver que entre 1808 e 1821, D. João VI concedeu títulos a quatro mil cavaleiros, 28 marqueses, oito condes, 16 viscondes e 21 barões, uma média aproximada de 6 títulos por ano. Dos agraciados, apenas quatro eram brasileiros natos: a baronesa de São Salvador de Campos e os barões de Santo Amaro, de São João Marcos e de Goiânia. Essa prodigalidade foi criticada por Pedro Calmon, afinal, tornar-se conde em Portugal exigia 500 anos e no Brasil 500 contos. A dinastia de Bragança em Portugal, por exemplo, concedeu apenas 54 títulos de nobreza, entre 1640 e 1706: 16 marqueses, 26 condes, 8 viscondes, 4 barões. A partir de então, face a crise econômica que se ampliava, os reis passaram também a serem mais flexíveis na concessão de mercês, sobretudo na nobilitação da burguesia mercantil, criando uma distinção crescente entre uma nobreza tradicional e empobrecida de capa e espada, por uma nova nobreza enriquecida pelo comércio.Mas D. Pedro I e D. Pedro II foram muito mais pródigos. 
D. Pedro I realizou quase a metade de todas suas mercês em 1826, ano em que teve início a crise de seu governo. No total, ele concedeu uma média de 16 títulos por ano. D. Pedro II em seus 49 anos à frente do Império foi bastante generoso em concessões de títulos; uma média superior a 25 por ano, mas o elevado número de barões, por exemplo, a partir de 1868 era um paliativo para agradar proprietários de terra ante a abolição iminente. Mulheres também foram agraciadas pelos imperadores brasileiros: duas duquesas, quatro marquesas, cinco condessas, nove viscondessas e dez baronesas.

Os títulos não eram hereditários, eram dativos e ad personam, ou seja, valiam apenas para o agraciado, com sua morte eles retornavam para a Coroa passando a integrar o patrimônio heráldico do Império onde permaneceria in potentia até que fosse ou não novamente concedido pelo Imperador ${ }^{13}$. Para adquiri-los os peticionários deveriam pleitear ao ministro do Império, juntando comprovação de que não tinham nenhum impedimento (bastardia, exercer ofício mecânico, sangue infecto, crime de lesa-majestade), indicando sua árvore genealógica. Geralmente a comprovação se dava por meio de testemunhas honradas, já nobilitadas ${ }^{14}$. Listas eram encaminhadas ao imperador, duas vezes por ano e este decidia pela concessão da mercê. Às vezes ele concedia o privilégio mesmo sem ter sido feita a solicitação. Os custos para a aquisição do título eram de $750 \$ 000$ para barão, 1:025\$000 para visconde, 1:575\$00 para conde, 2:020\$000 para marquês e 2:450\$000 para duque, estipulados por alvará de 2 de abril de 1860. Além disso, era preciso pagar mais $366 \$ 000$ para o registro e $170 \$ 000$ para a confecção e aquisição do brasão ${ }^{15}$.

O lançamento dos títulos de nobreza era feito pelo escrivão de nobreza e fidalguia, responsável ainda pela expedição das cartas de nobreza e fidalguia, que eram assinadas pelo imperador, pelo ministro do Império, informando a graça da mercê e o título conferido ao recebedor. Durante muitos anos esse cargo foi ocupado por Possidônio Carneiro da Fonseca Costa, que morreu em 1854, aos 38 anos, com perturbações mentais. Os livros e papéis referentes ao Primeiro Reinado se perderam. Em seguida foi nomeado como Rei das Armas Luís Aleixo Boulanger, artista franco-português, professor de caligrafia de D. Pedro II, de suas irmãs e de suas filhas. Ele tentou recuperar as cartas mais antigas e perdidas, confeccionando um único livro os registros recuperados, concluído em 1872, que continha 121 registros de títulos e brasões. É com base nessa recolha de Boulanger e nos registros do visconde de Sanches de Baena que os barões Vasconcelos iniciaram o Arquivo Nobiliárquico Brasileiro ${ }^{16}$.

Entender esse processo de nobilitação implica vislumbrar a corte como uma hierarquia que se sobrepõe às demais, como uma rede que se configura como um princípio dominante e central, uma referência que se exerce em qual- 
quer ponto na vasta cartografia das relações de poder. Ou como diz Ladurie: "senhoria na base, monarquia no topo" 17 . Entender as relações que se configuram ao longo das hierarquias revela como a importância das posições, ao longo do eixo vertical e também nas suas expressões horizontais, ilumina a compreensão das trajetórias individuais, de grupos e, porque não, dos partidos ao longo da história do Império brasileiro ${ }^{18}$. Família ampliada, o rei quer conhecer e incorporar seus súditos ao governo. Quer sua colaboração. Talvez nisso, D. Pedro II tenha sido mais hábil que seu pai. Ou seja, a monarquia se sustenta sobre os grupos, expressões regionais e sobre as redes importantes de negócios existências. A frente destes estão aqueles que, numa sociedade hierarquizada e marcada pelo status como a brasileira, podem facilmente ultrapassar os umbrais da aristocracia nobiliárquica existente. Para isso era necessário o reconhecimento dos pares e a mercê do monarca.

De certa maneira, muito contribuiu para a construção de uma imagem negativa dos palacianos algumas atitudes dos validos de D. João VI, em meio a conturbada chegada ao Rio de Janeiro, quando foi difícil submeter moradores ilustres e de grandes posses aos protocolos e à etiqueta da corte, vistas como exotismo e artificialidade. Ainda mais quando estes moradores tiveram que ceder suas casas e palacetes para uma nobreza recém-chegada, cujo comportamento, além de diferente, criava um mundo à parte nas relações sociais até então vigentes. Mas, foram terminantes nesse movimento de rejeição figuras como Chalaça e José Bonifácio, que reforçaram na corte de D. Pedro I, com seu comportamento, a cristalização de uma imagem profundamente negativa dos palacianos e validos mais próximos do monarca, ao produzirem na população e, particularmente, em seus adversários políticos, atitudes de receio, repulsa e ódio.

No Quadro 1 (ver anexo) vê-se a disposição de alguns integrantes da corte de D. Pedro II entre 1845 e 1850 . Chama a atenção o aumento sempre progressivo da nobreza imperial, representado pelo ingresso constante de moços-fidalgos e moços da Imperial Câmara. Nos demais postos, há apenas um pequeno aumento no número de veadores e de damas honorárias feito, inclusive, no sentido de acompanhar o aumento da nobreza. A média de gentis-homens é de 40 para estes cinco anos, de veadores de 31, veadores honorários 5 e guarda-roupas 12 .

A historiografia reporta Paulo Barbosa como mordomo-mor, mas ao longo de todo período este posto ficou vago. Barbosa era apenas mordomo da corte. Em 1846 ocupou este posto o ministro do Império, Joaquim Marcelino de Brito. Do mesmo modo, Itanhaém era visto sempre como o estribeiro-mor, embora tenha assumido o cargo Antônio Pedro Teixeira em 1846 e em 1849 e José Maria Velho da Silva em 1847. A Condessa de Belmonte foi a única camareira durante todo 
esse período, morando em um aposento do Paço, tendo a acompanhado neste mister a marquesa de Aguiar e a marquesa de Maceió. Como damas serviram, dentre outras a condessa de Itapagipe, D. Catarina Ramos Montaury, D. Maria Francisca Lobato, D. Joaquina Adelaide de Verna, D. Leopoldina Isabel de Verna, D. Elisa Francisca de Beaurepaire, D. Rita Francisa Rose, D. Maria Isabel de Ramos Montaury, D. Josefina da Fonseca Costa e D. Rosa de Sant'Anna Lopes.

Outro aspecto considerável foi o crescimento dos moços-fidalgos que foram integrados na corte, em número que se amplia em média aproximada de $20 \%$ ao ano. Trata-se do primeiro degrau em que a nobreza reconhece os filhos e descendentes de antigos nobres para colocá-los no caminho da nobilização.

Dentro deste universo palaciano na primeira metade do Segundo Reinado aquele que mais se destacava era Aureliano Coutinho. Militar, bacharel em Direito, comerciante, político, jornalista e diplomata, era figura querida do jovem imperador. Seu êxito político foi auferido após o combate dado aos exaltados durante as regências e a vitória sobre José Bonifácio, que foi destituído da tutoria de D. Pedro II após inflamados ataques desferidos entre 1832 e 1834 de seu jornal $A$ Verdade $^{19}$. Depois Aureliano escreveu também no Sentinela da Verdade, entre 1837 e 1840, cujo proprietário era seu irmão Saturnino.

$\mathrm{Na}$ casa de Aureliano eram dados concorridos bailes, onde se reunia boa parte da elite carioca e também inúmeros estrangeiros, sendo pessoa conhecida no Rio. Um dos ataques desferidos por Vasconcelos procurou encontrar nesses bailes, em que eram usadas as alfaias do barão do Rio Seco, motivo dos favores e da compra superfaturada de uma propriedade deste mesmo nobre durante a atuação de Aureliano à frente da pasta da Justiça, que não foi provada. Visconde de São Leopoldo era outro afeto de Aureliano.

\section{A FACÇÃo ÁUlica de AURELIANo COUTINHo}

Ao estudar os integrantes da facção áulica de Aureliano Coutinho nota-se que constituíram uma verdadeira linhagem de homens de Estado, pois um espaço considerável do governo era preenchido por indivíduos cujas raízes estavam na carreira militar e que, também, exerceram funções representativas no exterior. Ou seja, permitem ver que nem só de partidos vivia a política imperial e que o valimento era um instrumento de peso para a ascensão na alta burocracia do Estado. Aureliano Coutinho - diante de sua trajetória e dos textos a ele dedicados - representou, de fato, um elemento centrípeto nas redes de poder e que sua facção áulica efetivamente constituiu uma força que exerceu uma considerável influência no jogo e no imaginário político do início do Segundo Reinado. Vale lembrar que, o fato de sua atuação ocorrer nos bastidores do poder, fez com que sua influência permanecesse velada, visto não deixar pistas claras de suas ingerências. A rigor, como 
vestígios, sobraram apenas intrigas, dois panfletos e alguns discursos. Resta fazer o levantamento dos vínculos comerciais mantidos por Aureliano Coutinho, como mais uma tentativa de identificar os membros da facção áulica.

D. Pedro II, ao longo de sua vida, não teve muitas pessoas íntimas em seu convívio. E muitos políticos também se mantinham afastados para evitar, justamente, acusações de aulicismo. Mas, o imperador atalhava intimidades, salvo poucas exceções, como as "do marquês de Paraná, do visconde de Rio Branco, de Caxias, do marquês de São Vicente e de José Antônio Saraiva"20. Acrescento ainda o marquês de Itanhaém - que sucedeu Bonifácio na tutoria - e o duque de Caxias. Quando moço sua companhia se limitava ao trato com José Bonifácio e em seguida, a Aureliano, Paulo Barbosa da Silva - seu mordomo-mor entre 1834 e 1845 -, Cândido José de Araújo Viana - visconde de Sapucaí -, Luís Pedreira do Couto Ferraz, Francisco Otaviano, frei Pedro de Santa Mariana, que era seu diretor geral de estudos, além de Dadama ${ }^{21}$ e seus outros poucos mestres e professores ${ }^{22}$. Aproximar-se de sua figura e angariar sua simpatia era fundamental para se consolidar uma posição de destaque na corte.

A facção áulica teve seu aparecimento mais efetivamente na abdicação de D. Pedro I e se constituiu numa força política de considerável influência no governo a partir de 1834, após se projetar na corte, superando outros grupos palacianos importantes como os de José Bonifácio, de Holanda Cavalcanti, do marquês de Abrantes, do visconde de Olinda, combatendo Bernardo Pereira de Vasconcelos e resistindo à paulatina projeção do grupo de Honório Hermeto Carneiro Leão ${ }^{23}$, que em 1848 ao lado do visconde de Itaboraí sucedeu em São Cristóvão o prestígio da facção áulica. Em todo esse tempo, forçoso é lembrar, jamais se apagou a consideração que D. Pedro II tinha por Araújo Lima e, sobretudo, por Caxias. Assim, dos bastidores do poder os áulicos, particularmente, seu líder Aureliano Coutinho, assumiram uma posição estratégia unindo validos do Primeiro Reinado e novos validos, construindo redes de solidariedade cujo principal vínculo não era exclusivamente formado pelos negócios ou pelos casamentos, mas, sobretudo, em iniciativas filantrópicas e culturais como um instrumento de projeção social e política, cujo alcance tinha, como mérito, aproximar brasileiros ilustres que viviam no Rio de Janeiro, mas, também, estrangeiros, comerciantes, artistas, intelectuais, desembargadores e diplomatas.

A presença dos áulicos em meados do período regencial revela que não foram partidos políticos que conduziram a política brasileira de 1822 a meados de 1842, mas forças políticas que, em determinados momentos se coligaram, a partir de algumas causas comuns. Nos acontecimentos verificados, sobretudo a partir de 1831, é que as práticas políticas vivenciadas e a experiência política acumulada, em um processo que adquire um caráter de aceleração fez com que as lutas 
políticas engendrassem os partidos ${ }^{24}$. Assim, não foram liberais ou conservadores que deram as cartas do jogo político de 1822 a meados de 1840, mas grupos palacianos. O período regencial corresponde a um momento de aceleração, onde nova consciência histórica adquire seu momento crítico reequalizando o espaço de experiência e o horizonte das expectativas políticas. Consciência histórica que passava por um momento de transformação desde a vinda da família real, em 1808, aprofundada pelas jornadas de emancipação a partir de 1820 e pela Abdicação de 1831. Naquele contexto é notável a alteração no vocabulário político, na avaliação das tradições vivenciadas, na releitura das relações entre Brasil e Portugal, no reexame do passado. Embora essas mudanças fossem sentidas, oferecendo subsídios à crítica, foi efetivamente a crise, e, sobretudo, a crise posterior à Abdicação, responsável pelo caráter mais acentuado nas mudanças, que de maneira veloz produziu novos atores políticos e instituições - conhecidas como sociedades - que, a seu modo, serviram de catalizadoras no processo de engendramento dos partidos políticos ${ }^{25}$. Em sua atuação na esfera pública, as disputas políticas deixam o anonimato, as lojas secretas e passam a fazer-se abertamente, identificando seus sujeitos e seus projetos, nas tribunas e na imprensa. Aqui há um momento decisivo para a formação partidária.

Enquanto permaneciam em processo de formação, os integrantes destas futuras agremiações político-partidárias viveram ressentindo-se da ação política decidida nos bastidores, no meio palaciano, onde circulavam as figuras de maior projeção e de vivência com o imperador, assumindo, portanto, influência e poder de decisão consideráveis no governo e na administração do período.

Sigamos, por ora, as pegadas de Aureliano Coutinho. Filho de um coronel de engenheiros, Aureliano nasceu em Niterói em 21 de julho de 1800. Teve educação primorosa no Seminário de São José, um dos melhores colégios do Rio de Janeiro, depois seguiu para a Academia Militar, em seguida obteve pensão de D. João VI para cursar Direito em Coimbra. Formado, voltou ao Brasil, trabalhou como juiz de fora e ouvidor em São João Del Rei e depois em Ouro Preto, de 1826 a 1830, onde se casou com filha de abastado comerciante. No Rio foi eleito deputado do Império entre 1830 e 1833. Vinculou-se ao grupo de Evaristo da Veiga, logo depois foi indicado presidente da província de São Paulo, onde permaneceu por três meses e retornou ao Rio de Janeiro, coadjuvando com Feijó na Justiça como intendente de polícia da corte. Com a saída de Feijó, Aureliano assumiu a pasta do Império e depois da Justiça, que acumulou com o ministério dos Estrangeiros. Em 1835 deixou o ministério e tornou-se desembargador no Rio de Janeiro. Neste momento já era uma das figuras mais temidas no Império. Após a Maioridade, foi novamente conduzido ao ministério dos Estrangeiros, escolhido conselheiro de Estado e nomeado senador em 1842, para a vaga do mar- 
quês de Barbacena, evento emblemático que não deve ser desprezado. Barbacena pode ter sido o fidalgo que franqueou a Aureliano a entrada na corte. Havia ainda chefiado o gabinete que sucedeu ao de José Clemente Pereira de 1829 e contava com as graças de D. Pedro por conta de ter arranjado sua nova esposa D. Amélia com a ajuda de Paulo Barbosa.

Coutinho esteve ainda à frente de negócios singulares: foi o fundador da Companhia de Ônibus do Rio de Janeiro, da Casa de Correição, do Monte Pio dos funcionários, um dos fundadores da Caixa Econômica do Rio de Janeiro, da nova Carioca e da colônia de Petrópolis. Recebeu várias condecorações como a do Grão Ducado de Hesse Darmestadt, da Grã-Cruz da Ordem Real da Bélgica, de Nossa Senhora da Conceição da Vila Viçosa de Portugal, da Real Ordem de Fernando de Nápoles, da Ordem de Carlos III da Espanha, de Alexandre Nevsky da Rússia, de Cavaleiro de São João de Jerusalém. Foi um dos fundadores e também vice-presidente do Instituto Histórico e Geográfico Brasileiro, membro da Sociedade Etmológica de Paris, da Sociedade Arqueológica de Bruxelas, da Real Associação das Ciências, Letras e Artes de Antuérpia, dentre outras. Foi Cavaleiro do Hábito da Rosa e Cavaleiro da Ordem de Cristo, Oficial da Ordem do Cruzeiro, Camarista Real (fidalgo a serviço exclusivo do Imperador), fidalgo da Casa Imperial (nobre vive no Paço), gentil-homem da Câmara de D. Pedro II (cargo mais nobre da corte, íntimo do monarca). Condecorado com a Grã-Cruz da Bélgica ${ }^{26}$.

Correndo os olhos por sua biografia pouco podemos aludir de suas relações pessoais, salvo o destaque que tivera na vida política e seu prestígio internacional. Mas, lendo as páginas de seu jornal, $A$ Verdade e mesmo o de seu irmão, editado tempos depois, Sentinela da Verdade, e conhecendo melhor suas relações pessoais com o imperador, com altos representantes do governo brasileiro, com desembargadores, comerciantes e adidos de países estrangeiros é que se tornam visíveis sua influência e seu poder. Nunca se vinculou a nenhum partido. Só para se ter uma idéia, Feijó pensou em Aureliano para assumir o posto da Regência no lugar dele ${ }^{27}$.

Na carreira militar, Aureliano conheceu Paulo Barbosa da Silva, um militar que prestou serviços relevantes ao país, com estudos no exterior, poliglota, de hábitos refinados, adido diplomático em vários países da Europa e um dos idealizadores da futura cidade de Petrópolis ${ }^{28}$. Barbosa foi escolhido por Aureliano como o mordomo da corte. Para além de dedicar-lhe os serviços e a atenção, certamente Barbosa era seus olhos e ouvidos para tudo que se passasse no Paço. A relação entre os dois revela uma das primeiras características dos integrantes do grupo a que pertenceram, supostamente liderado por Aureliano: eram militares ou filhos de militares na burocracia do Primeiro Reinado. Juntos foram os 
redatores principais do jornal A Verdade que circulou entre 1833 e 1834, vinculado aos moderados.

Paulo Barbosa era filho de um coronel do $1^{\circ}$ Regimento de Cavalaria de Sabará, Minas Gerais, nascido em 1790. Seguiu a carreira militar, na qual chegou ao posto de general de Brigada. Em 1817 transferiu-se para o Rio de Janeiro, onde permaneceu para freqüentar a Academia Militar a despeito de sua companhia ter se deslocado para combater em Pernambuco. Durante toda a questão das Cortes de Lisboa permaneceu defendeu os interesses brasileiros, colocandose ao lado das tropas leais a D. Pedro I. Foi enviado a São Paulo e a Minas Gerais como emissário para divulgar a causa da Independência, que se tornou vitoriosa em 1822. Retomou então os estudos na Academia Militar e logo depois foi responsável pela execução das obras de fortificação em Macaé e em Cabo Frio. Em seguida foi nomeado comandante do Batalhão em Irajá. Nessa altura já havia recebido a Ordem de Cristo e também a Cruz da Ordem de Aviz em recompensa aos seus serviços, anos depois a Ordem da Rosa. Em 1825 foi para Paris aperfeiçoar-se nas técnicas militares e fez vários cursos, retornando ao Brasil somente em 1828. Tornou-se figura de confiança de D. Pedro I que o nomeou como moço da Imperial Câmara. Em 1829 seguiu para a Rússia em missão diplomática. Em Londres o visconde de Barbacena pediu-lhe que fosse a Viena auxiliá-lo nas negociações para o segundo casamento do imperador. Foi Paulo Barbosa que tratou pessoalmente com a corte austríaca os principais acertos para o matrimônio com Amélia de Leuchtenberg. Retornou ao Brasil somente em 1832, após a abdicação de Pedro I. Em 1833 auxiliou Pinto Peixoto a sufocar a revolta restauradora ocorrida em Minas Gerais, embora todos os líderes do movimento tenham sido anistiados em 1835. Neste mesmo ano, além de guardaroupas imperial, acumulou os cargos de mordomo-interino e guarda-jóias. Foi convidado também para fazer parte do Conselho Privativo do jovem imperador. Eleito deputado geral foi responsável por uma série de projetos de leis importantes como a da criação de um Liceu de Humanidades e de uma Faculdade de Ciências Naturais no Rio. Em 1845, depois de exercer o cargo de mordomo-mor entre 1840 e 1844, seguiu para a embaixada brasileira em São Petesburgo. Em 1847 transferiu-se para Berlim, em 1849 para Viena e em 1850 novamente voltou à Rússia. Retornou ao Brasil em 1854 com a saúde debilitada. A partir desse momento dedicou-se exclusivamente aos afazeres da corte, ao imperador e à construção de Petrópolis. Faleceu em 28 de janeiro de 1868. Em sua biografia sintetiza-se uma imagem clara:

Cidadão bem quisto em sua pátria, P. Barbosa soube submeter ao Brasil seu braço de soldado, seu coração de patriota, sua inteligência esclarecida de homem político e de diplomata, seu 
zelo ardente, sua fidelidade sem prova, sua índole, seu amor à infância sagrada dos augustos pupilos de sua Pátria, rendendo-lhes cuidados até a sua morte, tributando seus serviços preciosos à pessoa e à Corte do Imperador ${ }^{29}$.

Para os contemporâneos, Barbosa era o braço direito do visconde de Sepetiba, que por seus atributos eram identificados como as lideranças da facção áulica. Indício seguro, no vocabulário da época, de encetar um grupo cuja ação era vista com reservas, afinal, faccioso era sujeito que agia à revelia da lei e facção força política não reconhecida como legítima no jogo político.

\section{A OPACIDADE DA FACÇÃo ÁULICA}

Analisando os indivíduos que foram vinculados à facção áulica pelos contemporâneos, algumas semelhanças parecem surgir. Além de militares ou filhos de militares, quase todos eram do Rio de Janeiro e seus pais haviam pertencido à alta burocracia do Primeiro Reinado. Portanto, não afrontavam a geração coimbrã, representaram ao contrário, a reintegração daqueles portugueses que haviam adotado o Brasil como morada e que ainda ocupavam postos importantes do Estado imperial, a despeito do desgaste de muitos após a derrocada do governo de D. Pedro I. A estratégia do grupo deixa entrever que procuravam ocupar espaços privilegiados junto a essa alta burocracia nobiliárquica de acesso íntimo ao monarca. Também tinham contato com altos representantes de governos estrangeiros - isso num momento em que o Brasil renovava tratados de amizade, comércio e cooperação -, o acesso à alta magistratura - sobretudo desembargadores da relação da corte - a presença junto a órgãos policiais e fiscais na corte e na Alfândega. Colocavam-se também à frente de empreendimentos filantrópicos, educativos e culturais, para além da associação em negócios. Possuíram, subscreviam e escreviam em jornais. E além de interesses econômicos e políticos, do prestígio social que tinham, os áulicos faziam questão de se envolver em projetos civilizatórios e culturais ${ }^{30}$, participando de grêmios, instituições, associações e sociedades científicas e culturais no Brasil e no exterior. Falavam sempre duas ou mais línguas. Ou seja, eram indivíduos de projeção política e social na corte, reconhecidos em muitas províncias e também no exterior. Poderiam bem ser subsumidos à rubrica de cosmopolitas. Uma de suas cruzadas civilizatórias mais vitoriosas foi a participação direta na fundação do Instituto Histórico e Geográfico Brasileiro em 1838, do qual tiveram apoio irrestrito de um jovem estudioso e amante dos livros, o imperador.

Resta saber quem foram ao todo, os indivíduos que compunham a facção áulica. Além de Aureliano, mas efetivamente, em torno deste, poderíamos juntar o mordomo-mor Paulo Barbosa da Silva, Cândido José de Araújo Vianna (viscon- 
de de Sapucaí), Manuel de Andrade Souto Maior Pinto Coelho (marquês de Itanhaém), frei Pedro de Santa Maria (futuro bispo de Crisópolis), Saturnino de Souza e Oliveira (irmão de Aureliano), José Domingues Moncorvo (seu cunhado), Joaquim José de Azevedo - visconde do Rio Seco -, José Feliciano Fernandes Ribeiro (visconde de São Leopoldo, amigo íntimo de Aureliano), José Martins da Cruz Jobim, João Paulo dos Santos Barreto e Antônio Pinto Chichorro da Gama, além de Mariana Carlota de Verna Magalhães Coutinho, primeira e única condessa de Belmonte, camareira-mor nomeada por D. Pedro I, destituída por José Bonifácio em 1832 e reconduzida ao posto por Aureliano em 1834. Forçoso é dizer que a historiografia pouco considera a importância desta, como de outras importantes figuras femininas na corte, na condução dos negócios políticos. Foi o afastamento dela, por José Bonifácio, que levou à destituição do tutor, seguramente graças às informações que ela possuía e continuava colhendo de seus amigos na corte.

Localizar outros integrantes da facção é mais difícil. Outros nomes são também prováveis, como o do visconde de Barbacena, Raymundo José da Cunha Mattos, cônego Januário da Cunha Barbosa, Venâncio Henriques de Rezende, José Antônio da Silva Maia, José Antônio Lisboa, Caetano Lopes Gama e o magistrado e senador José Clemente Pereira. É ainda possível que outros membros fundadores do Instituto Histórico e Geográfico Brasileiro, também possuíssem vínculos com os áulicos, ou ainda tivessem sido integrantes do grupo, notadamente aqueles cujos pais integraram o funcionalismo público ou participaram da alta burocracia estatal durante o governo de D. Pedro I ${ }^{31}$. Uma hipótese a se considerar são possíveis laços existentes entre Antônio da Silva Pinho, Aureliano, Caetano Maria Lopes Gama, Cândido José de Araújo Viana, Montezuma, José Antônio da Silva Maia, José Clemente Pereira, Rodrigo Silva Pontes e José Marcelino R. Cabral, todos formados em Direito em Coimbra na mesma época, vale lembrar, contudo, que Aureliano rompeu com Montezuma e depois se apartou também de Lopes Gama.

A seguir foram relacionados em quadros e tabelas alguns indivíduos que tiveram contato direto com Aureliano, freqüentando sua casa, seus bailes, ou colaborando em seu jornal A Verdade. Igualmente aqueles cuja trajetória desenvolveu-se sob seu patrocínio direto. Assim, mesmo não sendo possível traçar uma relação umbilical entre Aureliano e José Clemente Pereira, é possível encontrá-los juntos, combatendo Bonifácio, associando-se na criação da Caixa Econômica do Rio de Janeiro, envidando esforços em obras filantrópicas em relação aos desvalidos na corte $^{32}$. Evidentemente que Pereira não seguia ordens de Aureliano, algo semelhante em relação a Cândido José de Araújo Vianna e ao marquês de Itanhaém. Ambos não poderiam ser pensados como lacaios, visto possu- 
írem dignidade e nobreza que antecedem à fidalguia de Sepetiba. Pretende-se tão somente indicar algumas pessoas que estiveram próximas e que também compuseram a facção áulica, para serem estabelecidas algumas características e afinidades relativas ao grupo.

\section{À GUISA DE INTERPRETAÇÃO: AURELIANO E ALGUNS PALACI- ANOS DE SEU CÍRCULO.}

Os quadros que ora se apresentam não são exaustivos, tampouco procuram registrar um grupo coeso liderado por Aureliano Coutinho. Foram apenas reunidos alguns indivíduos identificados com o aulicismo no início do Segundo Reinado, um e outro expoente da alta nobreza e também outros sem expressão nobiliárquica, cuja carreira política que não ultrapassa os degraus iniciais da burocracia imperial. Mas eles são capazes de ilustrar uma rede formada em torno da corte, visto freqüentarem São Cristóvão e terem convivido com Aureliano.

Chama a atenção no Quadro 2 (ver anexo) o fato de que quase todos eram filhos de militares do Primeiro Reinado. Homens que combateram nas jornadas de Independência ao lado de D. Pedro I e que chegaram a altos postos do Império. Alguns tiveram muitas posses, outros se envolveram em atividades comerciais, e todos encaminharam seus filhos para a carreira pública, incentivando os estudos e a formação superior, promovendo a mediação com a corte, na obtenção de títulos de nobreza e no trato com os validos, garantindo a inserção de seus protegidos. Quase todos foram agraciados com bolsas de estudo na Europa. Dos 15 apontados, apenas três não eram filhos de militares. De Antônio Pinto Chichorro da Gama não foi possível localizar a atividade paterna. Francisco de Salles Torres-Homem era filho bastardo de um padre e Bento da Silva Lisboa descendia de um grande magistrado e erudito do Primeiro Reinado, o visconde de Cairu.

Apenas cinco não receberam títulos de nobreza, perfazendo um terço do grupo recortado, um deles certamente por sua morte precoce, o irmão de Aureliano, Saturnino de Souza e Oliveira. Dos outros quatro, Paulo Barbosa, Cruz Jobim, Santos Barreto e Chichorro da Gama chama a atenção o fato de que os dois primeiros, ainda que freqüentassem o Paço e a corte, não eram exatamente figuras de amizade fraterna com o imperador, que certamente os via mais como funcionários. Santos Barreto e Chichorro da Gama também não tiveram grande expressão em São Cristóvão, ambos fizeram tentativas frustradas de se tornar senadores e o último com o agravante dos contratempos vividos na Revolução Praieira em Pernambuco ${ }^{33}$.

Seis eram cariocas, três mineiros, dois paulistas, dois baianos e dois portugueses, mas todos residiram no Rio de Janeiro. E observando missões diplomáti- 
cas e algumas informações biográficas foi possível perceber outra característica do grupo: dois membros falavam apenas duas línguas - a materna e mais outra, oito falavam três, quatro falavam quatro idiomas e somente um cinco. Este era o marques de Sapucaí, mestre de D. Pedro II, um dos homens mais cultos de seu tempo, poliglota, dono de erudição considerável e de uma das maiores bibliotecas particulares do Rio de Janeiro como pudemos atestar em seu inventário post mortem $^{34}$. Predomina a formação em Direito, dez ao todo, boa parte em Coimbra. Em seguida surgem três formados em Engenharia, um em Matemática e dois em Medicina. Um destes médicos era Torres-Homem, que também havia cursado Direito em Paris sob o patrocínio de Aureliano.

Analisar as atividades que exerceram também é elucidativo do comportamento daqueles indivíduos como indica o Quadro 3. Apenas um declarou ser agricultor, embora muitos tivessem propriedades. Do mesmo modo, apenas dois anunciaram explicitamente atuar no ramo do comércio. Apenas um exerceu a profissão de engenheiro e somente dois praticaram a medicina. Um indivíduo ocupou a Provedoria da Fazenda, outro a Presidência do Tribunal de Comércio, também um o Juizado de Órfãos, a Intendência de Polícia e também apenas um indivíduo declarou explicitamente exercer o jornalismo - embora vários outros tenham mantido folhas e colaborado com certa assiduidade nos jornais do Império. Dois foram inspetores de alfândega, como também apenas dois foram ouvidores. Cinco foram juízes, três desembargadores e seis exerceram a carreira militar. Cinco atuaram no magistério, dando aulas. Na burocracia imperial os números são reveladores: cinco foram presidentes de província, sete diplomatas, 11 deputados gerais - apenas quatro não chegaram ao Parlamento -, nove foram ministros, dez senadores e seis ocuparam o Conselho de Estado. Como se vê comércio e agricultura não eram, de fato, a atividade primordial do grupo. Isso nos remete ao caráter palaciano, em que os postos na carreira burocrática, ou seja, no serviço público, surgem como principal fonte de sustento e de prestígio. Um terço deles foram professores em algum momento da carreira, o que indica a inclinação pedagógica e a importância dada à educação. Seis foram militares, indício que preservaram vestígios das atividades realizadas pelos pais. Muitos foram juízes e três desembargadores. Medicina e engenharia eram carreiras menos procuradas.

No Quadro 3 (ver anexo) aparecem três sacerdotes, todos atuavam exclusivamente no Rio de Janeiro, o que indica a restrição do grupo ao universo da corte, cidade mais importante do Império, a capital. Um terço presidiu alguma província, sete, ou seja quase a metade exerceu alguma atividade ou integrou alguma missão diplomática, 74\% do grupo ocupou cadeiras no Parlamento, 60\% encarregaram-se de ministérios, $2 / 3$ foram senadores e $47 \%$ chegaram ao posto mais elevado do Império, ocupando o Conselho de Estado. 
Em relação às províncias onde atuaram, todos tiveram atividades no Rio de Janeiro em algum momento da carreira, o que os colocou em contato com a corte. Depois, observa-se que três passaram por São Paulo, cinco por Minas Gerais, três pela Bahia, dois por Pernambuco, dois por Alagoas, um pelo Maranhão, quatro pelo Rio Grande do Sul, dois pelo Espírito Santo e um pelo Pará.

No Quadro 4 (ver anexo), revelam-se outros aspectos importantes do conjunto, com atenção especial sobre o valimento. Pode-se perceber que apenas três permaneceram no início da condição de nobre, como gentis-homens, nove chegaram ao posto elevado de fidalgo cavaleiro da Câmara Imperial, um foi mestre do imperador, dois foram mordomos-mores, dois ocuparam o prestigiado posto de tutores, um foi condestável e três viadores ${ }^{35}$ das princesas e da imperatriz. O passo inicial para ingresso na nobreza e para o convívio na corte era iniciar na condição de moço-fidalgo, em seguida passando a gentil-homem e por fim a fidalgo cavaleiro. Condestável era o alferes-mor, o chefe dos generais de campo e guardião maior da corte.

Também salta aos olhos a quantidade de indivíduos que desempenhou missões diplomáticas, mais da metade do grupo, algo que revela o prestígio que detinham do governo imperial. Quase 60\% deles ocuparam a função de ministros em algum gabinete do Segundo Reinado, indicativo da sua representatividade política. Para coroar seu perfil cosmopolita, localizado na formação, nos idiomas que falavam, nas missões diplomáticas que fizeram parte, o Quadro 4 aponta também seu papel como homens de letras, integrando uma comunidade culta que exercia o exercício da escrita com frequência. Apenas quatro não legaram texto representativo ou não surgem como redatores de artigos, panfletos ou livros. Praticamente todos se ocuparam da escrita e redigiram textos significativos, quando não foram editores de jornais.

$\mathrm{Na}$ Tabela 2 (ver anexo) revela-se o quanto a faixa etária é equilibrada, metade era formada pelos mais jovens e menos titulados que tinham menos de 50 anos em 1840 e a outra metade era formada por aqueles mais velhos e mais titulados, homens que nasceram no final do século XVIII e que iniciaram a carreira durante o Primeiro Reinado. Fato revelador das solidariedades e estratégias envolvendo a facção. A outra parte do grupo ascende na política durante o período regencial, tendo nascido no início do século XIX, recebendo sua formação durante as regências, mas tendo expressão política posterior, durante o Segundo Reinado.

Destaco os três religiosos como figuras próximas de Aureliano, diretamente identificadas à facção áulica: o bispo de Crisópolis, Henriques de Rezende e o cônego Januário da Cunha Barbosa. Indício significativo de que a Igreja foi uma instituição estratégica para o grupo, com sua inserção política na sociedade de então, não somente por conta das homilias e influência dos padres incutindo e 
reproduzindo ideários junto à população do Rio de Janeiro ou ainda por ser nas igrejas onde se realizavam os pleitos eleitorais, mas também por sua importância nos circuitos culturais. Expoentes da comunidade letrada, intermediários entre o Estado e a sociedade, fazendo as vezes de cartório e preenchendo funções da esfera civil, os padres era figuras de projeção, destaque e admiração nas cidades. Seu apoio, portanto, garantia adesões e inspirava confiança.

$\mathrm{Na}$ Tabela 3 (ver anexo) indica-se a formação principal, relacionada com a titulação e a área de atuação dos indivíduos escolhidos. Majoritariamente fizeram curso superior, $83,4 \%$ no total, a maioria formada em Direito, seguido por Engenharia. Apenas 16,6\% não teve formação acadêmica: os três padres e Paulo Barbosa da Silva. Certamente esse foi um dos fatores que lhe cerrou as portas para uma carreira em cargos do governo, embora não haja indícios de que isso fosse de seu interesse mais imediato. A ênfase do grupo é o exercício de cargos burocráticos, somando $61 \%$ do total. Um quarto do grupo era representado por aqueles que exerciam a carreira militar.

Vínculos com o setor militar de inserção palaciana, expressão junto ao clero, contato com representantes consulares e comerciantes estrangeiros, integração com expoentes da sociedade carioca com trânsito na corte, participação em missões diplomáticas no exterior, proximidade com a alta magistratura, presença no Conselho de Estado e no Senado, participação em vários gabinetes, alianças entre remanescentes da velha corte joanina, de Pedro I e da nova corte de Pedro II, eis um perfil sumário para o grupo.

Na Tabela 4 (ver anexo) relaciona-se a presença da nobreza nos gabinetes imperiais entre 1831 e 1848. Optou-se por indicar todos os ministros que possuíam títulos, mesmo aqueles rivais ao grupo de Aureliano Coutinho. Os dados são reveladores. Logo na abdicação de D. Pedro I, o primeiro ministério não apresenta nenhum áulico, indício seguro de reação aos palacianos e de receio quanto à nobreza. Com a organização da Regência Permanente, o $1^{\circ}$ Gabinete tinha apenas dois áulicos, mas em seguida o número aumenta para $66,6 \%$ no segundo Gabinete e $100 \%$ no terceiro. Mesmo na adoção do Ato Adicional em 1834, o ministério era integralmente composto por áulicos. É nítido o esforço da alta nobreza, que se identificava com a alta burocracia, em não perder o controle do governo imperial. No Gabinete de 1835, cinco dos seis ministros eram integrantes da corte. Na Regência de Feijó o ingrediente palaciano continua presente, demonstrando que, a despeito do regente ser refratário a este grupo, não foi capaz de governar sem sua presença. Indicativo da pressão palaciana sobre um governo que havia realizado transformações profundas deixando sob ameaça a ordem monárquica. Nos últimos anos de sua regência o número de palacianos aumenta nos ministérios de Feijó. Por incrível que pareça na regência una de Araújo Lima o percentual de palacianos é 
menor que em relação a Feijó, inclusive com o $2^{\circ}$ Gabinete de 1839 tendo sido composto sem nenhum representante da alta nobreza.

Para se ter uma idéia da participação da nobreza titulada no governo imperial basta dizer que na Regência Trina Permanente eles ocuparam 67\% das pastas nos ministérios, na de Feijó esse percentual caiu para 50\%, na Regência de Araújo Lima desceu para 35\% das pastas. A diminuição dos palacianos nos gabinetes é acompanhada pari passu com o fortalecimento e a constituição partidária ocupando maior espaço nos ministérios. Durante as Regências, metade dos ministros possuíam títulos nobiliárquicos, ou seja, 39 dos 78 ministros. No Segundo Reinado, novamente 39 ministros possuíam títulos de nobreza nos gabinetes formados por D. Pedro II, de um total de 60 indicados.

No início do Segundo Reinado, entre 1840 e 1848, somente num único ano, 1848 , quando se formaram três gabinetes, constituiu-se o $9^{\circ}$ Gabinete sem nenhum áulico. Curiosamente foi o ano seguinte da denúncia sobre a existência da facção áulica feita no panfleto intitulado A Dissolução do Gabinete de 5 de maio ou a facção áulica de Firmino Rodrigues que agitou o debate político e a imprensa de então. Aquele foi um ano delicado, quando se dissolveu o Parlamento e encerrou-se a administração liberal no governo. Ao longo do período, contudo, o elemento palaciano é maciço. Sua presença confirma, a seu modo, a crítica em relação à urdidura dos ministérios, com sua origem áulica, palaciana. Mas, aqui se corrige o exagero do panfleto de Firmino. Seria impossível a Aureliano possuir, sozinho, tamanho poder na formação e dissolução destes ministérios. Há mais dúvida que certeza, pois, outros grupos palacianos disputaram com o de Aureliano espaços no poder, isso explica a expressiva presença de membros da nobreza em tantas pastas ao longo do período.

$\mathrm{Na}$ Tabela 5 (ver anexo) relaciona-se a presença dos palacianos em diferentes gabinetes, do período regencial até o início do Segundo Reinado. Novamente foram incluídos mesmo aqueles que não integravam o grupo de Aureliano Coutinho. Os dados indicam uma presença considerável de nobres nas pastas ministeriais. De um total de 189 ministros empossados entre 1831 e 1848, 113 eram integrantes da nobreza, ou seja, 59,7\%. Em relação aos ministérios, a presença áulica é mais significativa junto aos Estrangeiros, com quase $80 \%$ do total de ministros, ao passo que a menor presença é no ministério da Marinha, com 45,4\% seguido do ministério da Fazenda, com 50\% do total de titulares. Foram ministros dos Estrangeiros Aureliano, Saturnino e também Bento da Silva Lisboa, por exemplo. A pasta da Marinha era, tradicionalmente, aquela em iniciava o treinamento para os altos postos do governo. Era nela que regentes e depois D. Pedro II colocavam aqueles indivíduos que demonstravam possibilidade de galgar postos mais elevados da burocracia imperial. Já a Fazenda provavelmente 
tinha baixa incidência de áulicos certamente por ser uma das áreas mais delicadas, de maior exposição de seus titulares, podendo trazer maiores dificuldades aos palacianos, no sentido de que uma má gestão certamente traria desgaste à imagem pública do ministro. Como se vê o gráfico permite visualizar a forte presença áulica nos gabinetes e também elucida ainda mais suas áreas de atuação no governo imperial. Em primeiro lugar preferiam os postos relacionados à diplomacia, em seguida o ministério da Justiça com 70,5\%, pasta decisiva ao lado da Fazenda em relação às diretrizes a serem implementadas pela administração, após o Império com $60,6 \%$ - pasta onde podiam montar a máquina administrativa provincial sugerindo e acompanhando a atuação dos presidentes de províncias. Logo após surge o ministério da Guerra com 53,5\%, área na qual os pais de muitos dos áulicos haviam se dedicado desde a emancipação política do Império.

Por fim, vale dizer alguns dados referentes à presença de Aureliano e sua facção áulica, a fim de verificar a extensão da influência áulica ao longo de 18311848. No total foram 20 ministros com vínculos ao grupo, de um total de 189 , ou seja, aproximadamente $11 \%$. O período onde predominaram nos gabinetes foi de 1840 a 1846.

\section{CONCLUSÃO}

O triunfo dos áulicos se consubstanciou com a Maioridade, ao ganharem a adesão do jovem Pedro II, que entrou na causa atendendo ao "conselho de diversas pessoas que o cercavam" 36 ; por meio de uma aliança que fizeram com exrestauradores como os irmãos Andrada, liberais radicais e liberais moderados. Naquela ocasião, Aureliano havia se casado em segundas núpcias com a neta de José Bonifácio e, de certo modo a família dos Andrada serviu-se deste expediente para se reaproximar do poder. Embora Aureliano tenha sido marcado como aquele que liderou a facção áulica, talvez seja possível que dividisse ou que pelo menos se rescindisse diante da figura de Araújo Vianna, mestre e professor de D. Pedro II desde a infância, e, de Itanhaém que também tinha alta estima e consideração por seus pares, na corte, no Parlamento e no Senado.

A ascensão de D. Pedro II ao trono colocou a facção áulica no centro do governo imperial, das atenções e das decisões. A partir de então o grupo se tornou influente - pelo menos no que se depreende dos gabinetes de 1840 a 1846 onde existem membros do grupo liderando ministérios - e, num momento de constituição da política partidária, teve a condição de intervir nos negócios e na política, que inclusive influiu para a definição e consolidação dos partidos. A meu ver, de seu surgimento em 1832 capitaneado pelo jornal A Verdade passando pelo triunfo com vitória sobre o grupo de José Bonifácio em dezembro de 1833, depois pelo refluxo em 1837 com o regresso, a facção áulica teve seu triunfo maior em 
1840, com a Maioridade. Até 1848 deixou sua marca no governo imperial, a partir daí, com a consolidação os partidos e a ascensão dos saquaremas ao poder, o prestígio do grupo foi se esvaecendo.

É curioso como os conceitos em história, muitas vezes, acabam por metamorfosear o tempo em espaço. Assim, antes do tempo saquarema pode-se falar em anos áulicos, quando ingerências na condução da política, ensejaram a formação dos partidos, diferenciando-os e conferindo coerência a seus projetos políticos. Anos áulicos em que as principais figuras que se destacariam no Império, responsáveis pela construção do Estado, foram gestadas, inclusive o próprio imperador. Um período em que graves problemas institucionais foram vividos, onde as forças políticas formaram partidos, quando se formou uma elite que traria estabilidade e solidez ao regime monárquico. O princípio monárquico era uma referência na consciência político-partidária ligando expressões políticas do Primeiro e do Segundo Reinado. Essa ponte, promovida pelo congraçamento de validos antigos, com validos novos, urdiu-se pelos bastidores, foi costurada na corte, não nas províncias. Ela deu força a Aureliano, cuja atuação política foi um nó górdio desatado pela força política saquarema que, como novidade, introduz uma ação que valoriza as costuras provinciais e a direção do governo motivada por partidos, não homens. Acolhidos pela monarquia, referência angular na arena política, foram recebidos na ante-sala do poder por aqueles indivíduos que mantiveram acesas as chamas da tradição monárquica no Brasil, que promoveram um elo, ligando figuras exponenciais do Primeiro e do Segundo Reinado. Um mundo à parte, uma alta sociedade. Sucedidos por indivíduos que também souberam preservar essas tradições, aceitando de bom grado manter hábitos e etiquetas políticas, recebendo títulos nobiliárquicos, aceitando participar do jogo das interferências palacianas, por sua vez integrando o universo da corte ${ }^{37}$.

O predomínio de Aureliano pode ser localizado, efetivamente entre 1840 e 1848, menos de um decênio, pois aqui se desconsidera sua ascensão política após o triunfo sobre o grupo andradista em dezembro de 1833, o que lhe daria 15 anos de influência, período maior que o tempo saquarema. Esse dado oferece uma pista significativa do entendimento acerca das forças políticas em questão. De fato, tanto a presença da trindade saquarema no poder, com seu predomínio político, quanto a última rebelião liberal do período, a Praieira, ambos em 1848, coincidem com o refluxo da influência áulica. Naquele momento Aureliano já não contava mais com seu irmão, que havia falecido, bem como havia se separado de seu fiel escudeiro no Paço, Paulo Barbosa, que se encontrava em missões diplomáticas na Europa desde 1846. Chichorro da Gama em Pernambuco havia exposto ingerências áulicas e sua dupla rejeição para o Senado evidencia isto. Novos políticos, embora de sua mesma geração, encarregavam-se agora dos negó- 
e os bastidores da corte de D. Pedro II

cios da política, do mesmo modo que o imperador D. Pedro II, mais maduro e mais experiente, que interferia mais diretamente nas questões de poder. A maturidade do imperador, que supostamente manipularam no passado, bem como a cristalização dos conflitos e partidos políticos não deixavam espaços para que outras forças pudessem atuar no cenário político. Face à isto se deu o ocaso da facção áulica.

Aureliano que, na Galeria dos brasileiros ilustres de Sisson talvez tenha recebido o maior número de páginas, foi, por conta de sua suposta liderança de uma força política entranhada na corte que se negava à ingressar na política regular partidária, um político denegado na história do Império. Cujo papel não foi ainda devidamente elucidado, visto pairarem muitas dúvidas sobre seu real poder de intervenção nos gabinetes e sobre D. Pedro II. Cujas ligações pessoais ainda carecem de maiores estudos, visto não ter deixado pistas sobre suas maquinações nos bastidores da corte. Restam, suas alianças mercantis e familiares. Inclusive o curioso segundo casamento com a neta de José Bonifácio, político que ajudou a derrotar. Restam seus escritos. Como achincalhe, recebeu o nada carinhoso apodo de Couro de Anta. Apelido passado de pai para filho, pois, Aureliano de Souza e Oliveira Coutinho Filho, filho deste segundo casamento levou a alcunha de Couro de Anta Júnior.

\section{NOTAS:}

${ }^{2}$ HOLANDA, Sérgio Buarque de. História geral da civilização brasileira. Rio de Janeiro: Difel, 1989, v.5, p.95.

${ }^{3}$ SILVA, Firmino Rodrigues. A dissolução do gabinete de 5 de maio ou a facção áulica. 2.ed. Rio de Janeiro: Francisco Rodrigues de Paiva, 1901.

${ }^{4}$ Dentre as quais relacionamos algumas: GUIMARÃES, Lúcia Maria Paschoal. Debaixo da imediata proteção de Sua Majestade Imperial: o Instituto Histórico e Geográfico Brasileiro (I 838- | 889). RIHGB, v. 156, n॰388, p.459-613, jul./set., 1995; BLAKE, Augusto Victorino Alves Sacramento. Diccionario bibliographico brazileiro. Typographia Nacional, Rio de Janeiro, I893; BAENA, visconde de Sanches de. Archivo Heraldico Genealógico. Lisboa: Typographia Universal, I872; POLIANO, Luís Marques. Heráldica, pág. 372. Ed. GRD. Rio de Janeiro, 1986; CUNHA, Rui Vieira da. Estudo da nobreza brasileira. Brasília: Ministério da Justiça, 1969; BARMAN, Roderick J. Uma nobreza do novo mundo: a função dos títulos no Brasil imperial. Mensário do Arquivo Nacional. Rio de Janeiro, v.6, p.4-21, I973; BARÃO DE VASCONCELOS \& BARÃO SMITH DE VASCONCELOS. Archivo nobiliarchico brasileiro. Lausanne: Imprimerie La Concorde, 1918.

${ }^{5}$ OLIVEIRA, Ricardo. Valimento, privança e favoritismo: aspectos da teoria e cultura política do Antigo Regime. Revista Brasileira de História, v.25, n.50, 2005, p.6.

${ }^{6}$ HOLANDA, Sérgio Buarque de. História geral da civilização brasileira. Rio de Janeiro: Difel, 1989 , v.4, p.37.

${ }^{7}$ No Brasil, ao que parece apenas o marquês de Itanhaém e algumas camareiras moravam nas dependências de São Cristóvão em aposentos reservados durante o Segundo Reinado. 
${ }^{8}$ É conhecido o caso do visconde do Bom Retiro, Couto Ferraz, que pediu a D. Pedro II para não ser chamado a ministro, visto possuírem uma amizade que remontava à infância, evitando ser criticado por aulicismo. CANDIDO, Antonio. Um funcionário da monarquia. Rio de Janeiro: Ouro sobre Azul, 2002. 9 SILVA, Maria B. N. da. Ser nobre na colônia. São Paulo: Ed. Unesp, 2005, p.8.

10 Ibidem, p.215.

"Ibidem, p.221.

12 Ibidem, p.267.

${ }^{13}$ CUNHA, Rui Vieira da. op.cit., p. II.

14 BARMAN, Roderick. op. cit., p.4.

${ }^{15}$ CUNHA, Rui Vieira da. op. cit., p. 12.

16 BARÃO DE VASCONCELOS \& BARÃO SMITH DE VASCONCELOS. op. cit.

17 LADURIE, E. L. O estado monárquico. São Paulo: Companhia das Letras, 1999, p. 15.

18 Penso aqui na eficácia que uma abordagem baseada na sociologia figuracional de Norbert Elias poderia ter. Ver ELIAS, N. A sociedade de corte. Rio de Janeiro: Zahar, 2002.

${ }^{19}$ A Verdade, jornal miscellanico. Rio de Janeiro, 1832-4. Biblioteca Nacional.

${ }^{20}$ CARVAlHO, José Murilo. D. Pedro II. São Paulo: Companhia das Letras, 2007, 58.

21 Mariana Carlota de Verna Magalhães Coutinho, condessa de Belmonte.

${ }^{22}$ CARVALHO, José Murillo de. op. cit., p.34-6.

${ }^{23}$ Carneiro Leão era filho de Brás Carneiro Leão, comerciante de grosso trato, traficante de escravos, proprietário de terras e destacado membro da nobreza na corte de D. Pedro I.

${ }^{24}$ A formação político-partidária é aqui pensada na esteira da contribuição de Edward P. Thompson, como um processo construído a partir de práticas e experiências vivenciadas. THOMPSON, E. P. Tradicción, revuelta y consciência de classe. Barcelona: Paidós, 1983.

${ }^{25}$ A referência explícita aqui é o pensamento de Reinhart Koselleck, em sua análise da modernidade como um momento de aceleração e também seus conceitos angulares de consciência histórica, espaço de experiência e horizonte de expectativas. Há uma pertinência clara no uso desses conceitos para este momento da história brasileira. KOSELLECK, R. Futuro passado. Rio de Janeiro: Contraponto, 2006.

${ }^{26}$ SISSON, S. A. Galeria dos brasileiros ilustres. Brasília: Editora do Senado, 1999, v.2, p.473-4.

${ }^{27}$ Ibidem, p.470.

${ }^{28}$ Há uma biografia inédita sobre Paulo Barbosa da Silva, datada de 5 de junho de 1846 . Museu Imperial de Petrópolis. Fundo Paulo Barbosa. Biographie de P. Barbosa. Tombo 2853-97.

${ }^{29}$ Biographie de P. Barbosa, p.7.

${ }^{30}$ No jornal A Verdade se destacam matérias e notícias sobre colégios, ilustração, educação. Bem como inúmeros artigos falando do exterior, sobre acontecimentos e sobre suas instituições.

31 GUIMARÃES, Lúcia Maria Paschoal. Debaixo da imediata proteção de Sua Majestade Imperial: o Instituto Histórico e Geográfico Brasileiro (I 838- | 889). RIHGB, v. I 56, n³88, p.459-6 | 3, jul./set., 1995, p.473s.

${ }^{32}$ Clemente Pereira dirigiu a Misericórdia e Aureliano foi durante algum tempo Juiz de Órfãos na corte.

${ }^{33}$ Cf. MARSON, Isabel. O império do progresso - a revolução praieira em Pernambuco (I 842- | 855). São Paulo: Brasiliense, 1987.

${ }^{34}$ Arquivo Nacional. Marquês de Sapucaí. Vara Cível. Caixa 2.762, Notação 5.284, 1875.

35 Protetores.

${ }^{36}$ ALMEIDA, Tito Franco de. O conselheiro Francisco José Furtado: biografia e estudo de história política contemporânea. São Paulo: Nacional, 1944, p.27.

${ }^{37}$ Com exceção de Eusébio Queiroz, todos os expoentes do Partido Conservador e do Partido Liberal não se furtaram de receber títulos nobiliárquicos e de manter o costume de freqüentar a corte, embora D. Pedro II preferisse as audiências aos bailes. 
Palacianos e aulicismo no Segundo Reinado - a facção áulica de Aureliano Coutinho e os bastidores da corte de D. Pedro II 
210 REVISTA ESBOÇOS Volume 17, № 23, pp. 187-221 - UFSC

\section{Anexos}

TABELA 1 - Perfil da nobreza brasileira entre 1808-1889

\begin{tabular}{lcccc}
\hline & D. João VI & D. Pedro I & D. Pedro II & Total \\
\hline Duque & - & 3 & 1 & 4 \\
Marquês & 28 & 28 & 16 & 72 \\
Conde & 8 & 6 & 44 & 58 \\
Visconde & 16 & 32 & 181 & 229 \\
Barão & 21 & 45 & 813 & 879 \\
\hline Total & 73 & 114 & 1055 & 1242 \\
\hline
\end{tabular}

Fonte: BARÃO DE VASCONCELOS \& BARÃO SMITH DE VASCONCELOS. Archivo nobiliarchico brasileiro. Lausanne: Imprimerie La Concorde, 1918 e CUNHA, Rui Vieira da. Estudo da nobreza brasileira. Brasília: Ministério da Justiça, 1969. 
QUADRO 1 - Alguns integrantes da corte de D. Pedro II entre 1845 e 1850.

\begin{tabular}{|c|c|c|c|c|c|c|c|c|c|c|c|c|}
\hline Ano & Mordomo & $\begin{array}{c}\text { Estribeiro- } \\
\text { mor }\end{array}$ & $\begin{array}{l}\text { Gentis- } \\
\text { homens }\end{array}$ & Veadores & $\begin{array}{c}\text { Veadores } \\
\text { honorários }\end{array}$ & $\begin{array}{l}\text { Guarda- } \\
\text { roupas }\end{array}$ & $\begin{array}{c}\text { Guarda-roupas } \\
\text { honorários }\end{array}$ & Moço fidalgo & $\begin{array}{c}\text { Moço da Imperial } \\
\text { Câmara }\end{array}$ & Camareiras & Damas & $\begin{array}{c}\text { Damas } \\
\text { honorárias }\end{array}$ \\
\hline 1845 & Vago & Itanhaém & 41 & 26 & 3 & 14 & 25 & 79 & 54 & 2 & 9 & 29 \\
\hline 1846 & $\begin{array}{c}\text { Joaquim } \\
\text { Marcelino } \\
\text { de Brio }\end{array}$ & $\begin{array}{l}\text { Antônio } \\
\text { Bento } \\
\text { Teixeira }\end{array}$ & 40 & 26 & 4 & 13 & 23 & 83 & 55 & 2 & 9 & 28 \\
\hline 1847 & $\begin{array}{l}\text { Paulo } \\
\text { Barbosa }\end{array}$ & $\begin{array}{c}\text { José Maria } \\
\text { Velho } \\
\text { da Silva }\end{array}$ & 40 & 26 & 5 & 10 & 28 & 88 & 59 & 3 & 10 & 31 \\
\hline 1848 & $\begin{array}{l}\text { Paulo } \\
\text { Barbosa }\end{array}$ & Itanhaém & 40 & 26 & 5 & 9 & 29 & 100 & 57 & 2 & 10 & 34 \\
\hline 1849 & Vago & $\begin{array}{l}\text { Antônio } \\
\text { Pedro } \\
\text { Teixeira }\end{array}$ & 40 & 26 & 6 & 13 & 32 & 119 & 55 & 2 & 10 & 33 \\
\hline 1850 & Vago & Itanhaém & 37 & 26 & 9 & 13 & 31 & 128 & 50 & 1 & 10 & 34 \\
\hline
\end{tabular}

Fonte: Almanack Laemmert. Rio de Janeiro, 1845-1850. 
212 REVISTA ESBOÇOS Volume 17, Nº 23, pp. 187-221 - UFSC

QUADRO 2 - Aureliano e alguns palacianos: títulos, origem, formação e profissão paterna.

\begin{tabular}{|c|c|c|c|c|c|}
\hline Nome & Título & Nascimento & Idiomas & Formação & Atividade do pai \\
\hline 1. Aureliano Coutinho & Visconde de Sepetiba & Rio de Janeiro, 1800 & Quatro línguas & Direito Coimbra & Militar \\
\hline 2. Candido José de Araújo Viana & Visconde de Sapucaí & Minas Gerais, 1793 & Três línguas & Direito Coimbra & Militar \\
\hline $\begin{array}{l}\text { 3. Manuel Inácio de Andrade Souto } \\
\text { Maior Pinto Coelho }\end{array}$ & Visconde de Itanhaém & São Paulo, 1782 & Cinco línguas & Direito Coimbra & Militar \\
\hline 4. Francisco Vilela Barbosa & Marquês de Paranaguá & Rio de Janeiro, 1769 & Três línguas & Matemática Coimbra & Militar \\
\hline $\begin{array}{l}\text { 5. Felisberto Caldeira Brant Pontes } \\
\text { de Oliveira Horta }\end{array}$ & Marquês de Barbacena & Minas Gerais, 1772 & Quatro línguas & Engenharia Lisboa & Militar \\
\hline 6. José Feliciano Fernandes Ribeiro & Visconde de São Leopoldo & São Paulo, 1774 & Quatro línguas & Direito Coimbra & Militar \\
\hline 7. José Clemente Pereira & $\begin{array}{l}\text { Conde de Piedade } \\
\text { (in memoriam) }\end{array}$ & Portugal, 1787 & Três línguas & Direito em Coimbra & Militar \\
\hline 8. Paulo Barbosa da Silva & Não teve & Minas Gerais, 1790 & Quatro línguas & Engenharia Lisboa & Militar \\
\hline 9. Saturnino de Sousa e Oliveira & Não teve & Rio de Janeiro, 1803 & Duas línguas & Direito Coimbra & Militar \\
\hline 10. Joaquim José de Azevedo & $\begin{array}{l}\text { Visconde do Rio Seco e } \\
\text { Marquês de Jundiaí }\end{array}$ & Portugal, 1761 & Três línguas & Direito Coimbra & Militar \\
\hline 11. José Martins da Cruz Jobim & Não teve & Rio de Janeiro, 1802 & Três línguas & Medicina Paris & Militar \\
\hline 12. João Paulo dos Santos Barreto & Não teve & Rio de Janeiro, 1788 & Três línguas & Engenharia Lisboa e Paris & Militar \\
\hline 14. Francisco de Salles Torres-Homem & Visconde de Inhomirim & Rio de Janeiro, 1812 & Três línguas & $\begin{array}{l}\text { Medicina Rio de Janeiro } \\
\text { e Direito em Paris }\end{array}$ & Padre \\
\hline 15. Bento da Silva Lisboa & Barão de Cairu & Bahia 1793 & Três línguas & Direito & Magistrado \\
\hline 16. Bispo de Crisópolis & Não teve & Rio de Janeiro? & Três línguas & Sem informação & Sem indicação \\
\hline 17. Venâncio Henriques de Rezende & Não teve & Pernambuco1784 & Três línguas & Direito & Sem indicação \\
\hline 18. Januário da Cunha Barbosa & Não teve & Rio de Janeiro 1780 & Três línguas & Sem informação & Sem indicação \\
\hline
\end{tabular}

Fontes: Tavares de Lyra. Instituições Políticas do Império. Brasília: Senado Federal, 1978; Barão de Smith Vasconcellos. Archivo Brasileiro Nobiliarchico. In: http:/ /geocities.yahoo.com.br/ kajafreitas/dedicado.htm; S. A. Sisson. Galeria dos Brasileiros Ilustres. Brasília: Senado Federal, 1998. 2v. 
QUADRO 3 - Palacianos: cargos ocupados, regiões de atuação e entidades.

\begin{tabular}{|c|c|c|c|}
\hline Nome & Cargos & Áreas de atuação & Entidades que pertenceu \\
\hline Aureliano Coutinho & $\begin{array}{l}\text { Juiz de fora, ouvidor, presidente de } \\
\text { província, juiz de órfãos, intendente de } \\
\text { polícia, comerciante, desembargador, } \\
\text { diplomata, deputado, ministro, senador. }\end{array}$ & São Paulo, Minas Gerais e Rio de Janeiro & $\begin{array}{l}\text { IHGB, Sociedade Promotora da Indústria, } \\
\text { Membro do Supremo Tribunal de Justiça, } \\
\text { Sociedade Auxiliadora da Indústria Nacio- } \\
\text { nal }\end{array}$ \\
\hline $\begin{array}{l}\text { Candido José de Araújo } \\
\text { Viana }\end{array}$ & $\begin{array}{l}\text { Promotor, juiz de fora, desembargador, } \\
\text { ministro, conselheiro, presidente de } \\
\text { província }\end{array}$ & $\begin{array}{l}\text { Minas Gerais, Bahia, Pernambuco, } \\
\text { Alagoas, Rio de Janeiro, Maranhão }\end{array}$ & $\begin{array}{l}\text { Fiscal do Tesouro, Membro do Supremo } \\
\text { Tribunal de Justiça, IHGB, Sociedade } \\
\text { Auxiliadora da Indústria Nacional }\end{array}$ \\
\hline $\begin{array}{l}\text { Manuel Inácio de Andrade } \\
\text { Souto Maior Pinto Coelho }\end{array}$ & $\begin{array}{l}\text { General, coronel, agricultor, deputado, } \\
\text { senador }\end{array}$ & Rio de Janeiro, Minas Gerais & $\begin{array}{l}\text { IHGB, Sociedade Auxiliadora da Indústria } \\
\text { Nacional }\end{array}$ \\
\hline $\begin{array}{l}\text { Francisco Vilela Barbosa } \\
\text { Lente }\end{array}$ & $\begin{array}{l}\text { General, professor, deputado, diplomata } \\
\text { ministro, senador }\end{array}$ & Rio de Janeiro & Membro da Sociedade Real de Lisboa \\
\hline $\begin{array}{l}\text { José Feliciano Fernandes } \\
\text { Ribeiro }\end{array}$ & $\begin{array}{l}\text { Ouvidor, juiz de alfândega, tenente do } \\
\text { exército, deputado, presidente de provín- } \\
\text { cia, ministro, diplomata senador, conse- } \\
\text { lheiro }\end{array}$ & $\begin{array}{l}\text { São Paulo, Rio Grande do Sul, Rio de } \\
\text { Janeiro }\end{array}$ & $\begin{array}{l}\text { Criador dos cursos Jurídicos em São Paulo } \\
\text { e em Olinda. Reformou a Faculdade de } \\
\text { Medicina e a Academia de Belas Artes, } \\
\text { IHGB }\end{array}$ \\
\hline $\begin{array}{l}\text { Felisberto Caldeira Brant } \\
\text { Pontes de Oliveira Horta }\end{array}$ & $\begin{array}{l}\text { Militar, ministro, conselheiro de Estado, } \\
\text { diplomata, comandante geral de armas }\end{array}$ & $\begin{array}{l}\text { Minas Gerais, Bahia, Rio de Janeiro, Rio } \\
\text { Grande do Sul }\end{array}$ & Diretor do Banco do Brasil na Bahia \\
\hline José Clemente Pereira & $\begin{array}{l}\text { Magistrado, juiz de fora, ministro, depu- } \\
\text { tado, senador, conselheiro, Presidente do } \\
\text { Tribunal de comércio }\end{array}$ & Rio de Janeiro & $\begin{array}{l}\text { IHGB, Presidente da Santa Casa de Miseri- } \\
\text { córdia, Criador do Hospício do Rio de } \\
\text { Janeiro. }\end{array}$ \\
\hline$\underline{\text { Paulo Barbosa da Silva }}$ & Militar, professor, diplomata & Minas Gerais, Rio de Janeiro & Um dos fundadores de Petrópolis \\
\hline $\begin{array}{l}\text { Saturnino de Sousa e Olivei- } \\
\text { ra }\end{array}$ & $\begin{array}{l}\text { Inspetor da alfândega, juiz, deputado, } \\
\text { senador }\end{array}$ & Rio de Janeiro, Rio Grande do Sul & $\begin{array}{l}\text { Inpetor da Alfândega em 1836-7 e em } \\
1844-6\end{array}$ \\
\hline Joaquim José de Azevedo & $\begin{array}{l}\text { Conselheiro Imperial de D. João VI e de } \\
\text { D. Pedro I }\end{array}$ & Portugal, São Paulo, Rio de Janeiro & Organizador da vinda para o Brasil 1808 \\
\hline
\end{tabular}


QUADRO 3 - Palacianos: cargos ocupados, regiões de atuação e entidades (cont.).

\begin{tabular}{|c|c|c|c|}
\hline Nome & Cargos & Áreas de atuação & Entidades que pertenceu \\
\hline José Martins da Cruz Jobim & $\begin{array}{l}\text { Médico do paço nomeado por Bonifácio, } \\
\text { professor, deputado RS, senador ES }\end{array}$ & $\begin{array}{l}\text { Rio de Janeiro, Rio Grande do Sul, Espíri- } \\
\text { to Santo }\end{array}$ & Fundou Academia Imperial de Medicina \\
\hline $\begin{array}{l}\text { João Paulo dos Santos } \\
\text { Barreto }\end{array}$ & $\begin{array}{l}\text { Militar, engenheiro, professor, presidente } \\
\text { de província, diplomata, deputado, } \\
\text { conselheiro }\end{array}$ & Rio de Janeiro, Pará & $\begin{array}{l}\text { Membro do Supremo Comando Militar do } \\
\text { Império }\end{array}$ \\
\hline $\begin{array}{l}\text { Antônio Pinto Chichorro da } \\
\text { Gama }\end{array}$ & $\begin{array}{l}\text { Juiz, provedor da fazenda, } \\
\text { desembargador, deputado, presidente de } \\
\text { província, ministro e senador }\end{array}$ & $\begin{array}{l}\text { Bahia, Rio de Janeiro, Espírito Santo, } \\
\text { Alagoas, Pernambuco }\end{array}$ & Presidente do Parlamento \\
\hline $\begin{array}{l}\text { Francisco de Salles Torres- } \\
\text { Homem }\end{array}$ & $\begin{array}{l}\text { Médico, jornalista, professor, comercian- } \\
\text { te, diplomata, deputado, ministro e } \\
\text { senador }\end{array}$ & Rio de Janeiro & Presidente do Banco do Brasil \\
\hline Bento da Silva Lisboa & Ministro, deputado e diplomata & Bahia, Rio de Janeiro & IHGB \\
\hline Bispo de Crisópolis & Padre & Rio de Janeiro & Sem informação \\
\hline $\begin{array}{l}\text { Venâncio Henriques de } \\
\text { Rezende }\end{array}$ & Padre, deputado & Pernambuco, Bahia e Rio de Janeiro & $\begin{array}{l}\text { Presidente do Parlamento Brasileiro duas } \\
\text { vezes }\end{array}$ \\
\hline Januário da Cunha Barbosa & $\begin{array}{l}\text { Padre, orador sacro, jornalista, poeta, } \\
\text { deputado }\end{array}$ & Rio de Janeiro & $\begin{array}{l}\text { IHGB, diretor da Biblioteca Nacional, } \\
\text { Sociedade Auxiliadora da Indústria Nacio- } \\
\text { nal }\end{array}$ \\
\hline
\end{tabular}

Fontes: Tavares de Lyra. Instituições Politicas do Império. Brasília: Senado Federal, 1978; Barão de Smith Vasconcellos. Archivo Brasileiro Nobiliarchico. In: http:/ /geocities.yahoo.com.br/ kajafreitas/dedicado.htm; S. A. Sisson. Galeria dos Brasileiros Ilustres. Brasília: Senado Federal, 1998. 2v. 
QUADRO 4 - Valimento e atuação político-diplomática.

\begin{tabular}{|c|c|c|c|c|}
\hline Nome & Valimentos & Missões no exterior & Ministérios ocupados & Textos publicados \\
\hline Aureliano Coutinho & Fidalgo cavaleiro & $\begin{array}{l}\text { Conselho Particular do Imperador } \\
\text { D. Pedro II }\end{array}$ & Inglaterra, França e Áustria & $\begin{array}{l}\text { Estrangeiros, da Justiça Jornal a } \\
\text { Verdade }\end{array}$ \\
\hline $\begin{array}{l}\text { Candido José de Araújo } \\
\text { Viana }\end{array}$ & $\begin{array}{l}\text { Professor de Pedro II, } \\
\text { Tutor das princesas, } \\
\text { Conselho do Impera- } \\
\text { dor }\end{array}$ & Nenhuma & Fazenda, Justiça e Império & Sem informação \\
\hline $\begin{array}{l}\text { Manuel Inácio de Andrade } \\
\text { Souto Maior Pinto Coelho }\end{array}$ & $\begin{array}{l}\text { Alferes-mor na } \\
\text { sagração de D. Pedro } \\
\text { ITutor de D. Pedro } \\
\text { II,Mordomo-mor }\end{array}$ & Nenhuma & Nenhum & $\begin{array}{l}\text { Relatório da Casa Imperial, jornal A } \\
\text { Verdade }\end{array}$ \\
\hline $\begin{array}{l}\text { Francisco Vilela Barbosa } \\
\text { Lente }\end{array}$ & $\begin{array}{l}\text { Condestável na coroa- } \\
\text { ção de Pedro II, } \\
\text { Fidalgo cavaleiro }\end{array}$ & $\begin{array}{l}\text { Portugal, reviu os tratados de } \\
\text { amizade com a França }\end{array}$ & Império, Marinha e Guerra & $\begin{array}{l}\text { Real Academia da Marinha, Real } \\
\text { Academia de Lisboa, Recebeu } \\
\text { vários prêmios da Academia Real } \\
\text { de Ciências de Lisboa por seu } \\
\text { trabalho na área das Matemáticas }\end{array}$ \\
\hline $\begin{array}{l}\text { José Feliciano Fernandes } \\
\text { Ribeiro }\end{array}$ & Viador das princesas & $\begin{array}{l}\text { Negociou a paz entre Brasil e } \\
\text { Argentina em 1827, do tratado de } \\
\text { amizade, navegação e comércio } \\
\text { com a Grã-Bretanha em } 1827, \\
\text { com a Prússia }\end{array}$ & Estrangeiros & $\begin{array}{l}\text { Escreveu os Anais da província do } \\
\text { Rio Grande do Sul, uma Memória } \\
\text { sobre os limites naturais, pactuados } \\
\text { e necessários ao Império do Brasil, } \\
\text { uma Vida e feitos de Alexandre } \\
\text { Gusmão, e ainda uma História } \\
\text { geral do Brasil. E também Memóri- } \\
\text { as, jornal A Verdade. }\end{array}$ \\
\hline $\begin{array}{l}\text { Felisberto Caldeira Brant } \\
\text { Pontes de Oliveira Horta }\end{array}$ & $\begin{array}{l}\text { Fidalgo cavaleiro, } \\
\text { encarregado do segun- } \\
\text { do casamento de D. } \\
\text { Pedro I }\end{array}$ & $\begin{array}{l}\text { Negociou a independência em } \\
\text { Londres }\end{array}$ & Império, Fazenda & $\begin{array}{l}\text { Defesa dos Negociadores do Em- } \\
\text { préstimo Brasileiro em Londres } \\
\text { Contra as Investiduras do Parecer } \\
\text { da Câmara dos Deputados, História } \\
\text { da Campanha no Sul, jornal Astréa }\end{array}$ \\
\hline
\end{tabular}


216 REVISTA ESBOÇOS Volume 17, N²3, pp. 187-221 - UFSC

QUADRO 4 - Valimento e atuação político-diplomática (cont.).

\begin{tabular}{|c|c|c|c|c|}
\hline Nome & Valimentos & Missões no exterior & Ministérios ocupados & Textos publicados \\
\hline José Clemente Pereira & $\begin{array}{l}\text { Conselheiro do Impe- } \\
\text { rador }\end{array}$ & Exílio em Lisboa & $\begin{array}{l}\text { Império, Fazenda, Justiça, } \\
\text { Estrangeiros, Guerra, Marinha }\end{array}$ & $\begin{array}{l}\text { Código Criminal, Código Comercial, } \\
\text { Defesa Oferecida aos Representantes } \\
\text { da Nação em } 10 \text { de junho de } 1831\end{array}$ \\
\hline Paulo Barbosa da Silva & Mordomo-mor & $\begin{array}{l}\text { Paris Portugal, Áustria, Prússia e } \\
\text { Rússia }\end{array}$ & Nenhum & $\begin{array}{l}\text { Memória sobre a fundação de } \\
\text { Petrópolis, jornal a Verdade }\end{array}$ \\
\hline $\begin{array}{l}\text { Saturnino de Sousa e Olivei- } \\
\text { ra }\end{array}$ & Gentil-homem & Missão em Portugal & Estrangeiros, Fazenda e Justiça & $\begin{array}{l}\text { Jornal A Verdade, jornal Sentinela da } \\
\text { Ordem }\end{array}$ \\
\hline Joaquim José de Azevedo & Viador de D. João VI & Missão em Portugal & Nenhum & Sem informação \\
\hline José Martins da Cruz Jobim & $\begin{array}{l}\text { Médico do Paço } \\
\text { Imperial }\end{array}$ & Missão na França e em Portugal & Ministro & jornal A Verdade. \\
\hline $\begin{array}{l}\text { João Paulo dos Santos } \\
\text { Barreto }\end{array}$ & $\begin{array}{l}\text { Fidalgo cavaleiro e } \\
\text { viador imperial }\end{array}$ & Portugal e França & Guerra duas vezes & $\begin{array}{l}\text { Reorganizou o Supremo Tribunal } \\
\text { Militar, jornal A Verdade }\end{array}$ \\
\hline $\begin{array}{l}\text { Antônio Pinto Chichorro da } \\
\text { Gama }\end{array}$ & Gentil-homem & Nenhuma & Império e Fazenda & Jornal A Verdade \\
\hline $\begin{array}{l}\text { Francisco de Salles Torres- } \\
\text { Homem }\end{array}$ & Fidalgo cavaleiro & $\begin{array}{l}\text { França (encarregado da Legação } \\
\text { dos Negócios) }\end{array}$ & Fazenda & $\begin{array}{l}\text { Timandro, A oposição e a Coroa, } \\
\text { vários jornais }\end{array}$ \\
\hline Bento da Silva Lisboa & $\begin{array}{l}\text { Gentil-homem, casa- } \\
\text { mento de D. Pedro II }\end{array}$ & $\begin{array}{l}\text { Missão Diplomática em França, } \\
\text { Áustria e Itália }\end{array}$ & Ministro dos Estrangeiros & Aurora Fluminense \\
\hline Bispo de Crisópolis & Capelão da Corte & Nenhuma & Nenhum & Sem informação \\
\hline $\begin{array}{l}\text { Venâncio Henriques de } \\
\text { Rezende }\end{array}$ & $\begin{array}{l}\text { Cônego da Capela } \\
\text { Imperial }\end{array}$ & Exilado em Lisboa & Nenhum & $\begin{array}{l}\text { Proclamações Republicanas } 1817 \text {, } \\
\text { jornal O Marimbondo }\end{array}$ \\
\hline Januário da Cunha Barbosa & $\begin{array}{l}\text { Cônego da capela } \\
\text { imperial }\end{array}$ & Não há & Nenhum & $\begin{array}{l}\text { Revista da Sociedade Auxiliadora da } \\
\text { Indústria Nacional, Revista do IHGB }\end{array}$ \\
\hline
\end{tabular}

Fontes: Tavares de Lyra. Instituições Politicas do Império. Brasília: Senado Federal, 1978; Barão de Smith Vasconcellos. Archivo Brasileiro Nobiliarchico. In: http:/ /geocities.yahoo.com.br/ kajafreitas/dedicado.htm; S. A. Sisson. Galeria dos Brasileiros Ilustres. Brasília: Senado Federal, 1998. 2v. Brasil 500 Anos. 
TABELA 2 - Idade dos áulicos em 1840

\begin{tabular}{lcccccccc}
\hline $\begin{array}{l}\text { Idade } \\
\text { Nomeação }\end{array}$ & 40 a 45 & 46 a 50 & 51 a 55 & 56 a 60 & 61 a 65 & 66 a 70 & Mais de 70 Total \\
\hline Total & 5 & 3 & 3 & 3 & - & 2 & 1 & 17 \\
\hline Percentual & $29,4 \%$ & $17,7 \%$ & $17,7 \%$ & $17,7 \%$ & - & $11,7 \%$ & $5,8 \%$ & $100 \%$ \\
\hline
\end{tabular}

Fontes: Tavares de Lyra. Instituições Politicas do Império. Brasília: Senado Federal, 1978; Barão de Smith

Vasconcellos. Archivo Brasileiro Nobiliarchico. In: http://geocities.yahoo.com.br/ kajafreitas/dedicado.htm; S. A.

Sisson. Galeria dos Brasileiros Ilustres. Brasília: Senado Federal, 1998. 2v. Brasil 500 Anos. 
218 REVISTA ESBOÇOS Volume 17, № 23, pp. 187-221 - UFSC

TABELA 3 - Formação, títulos e principal área de atuação profissional

\begin{tabular}{|c|c|c|c|c|c|c|c|c|c|c|}
\hline \multirow{2}{*}{$\begin{array}{l}\text { Atuação } \\
\text { principal }\end{array}$} & Formação & Sem formação & Sem títulos & & & Títulos & & & Total & $\%$ \\
\hline & Superior & Sup. & Título & Barões & Viscondes & Condes & Marqueses & Duques & & \\
\hline Política & 11 & - & 3 & 1 & 5 & - & 2 & - & 11 & 61,0 \\
\hline Militar & 3 & 1 & 2 & - & 2 & - & - & - & 4 & 24,4 \\
\hline Eclesiástica & 1 & 2 & 3 & - & - & - & - & - & 3 & 16,6 \\
\hline Total & 15 & 3 & 8 & 1 & 7 & - & 2 & - & 18 & 100 \\
\hline$\%$ & 83,4 & 16,6 & 44,5 & 5,5 & 38,9 & 0 & 11,1 & - & 100 & 100 \\
\hline
\end{tabular}

Fontes: Barão de Javari. Organizações e Programas Ministeriais. Rio de Janeiro: Departamento de Imprensa Nacional, 1962; Tavares de Lyra. Instituições Políticas do Império. Brasília: Senado Federal, 1978; Max Fleiuss. História Administrativa do Brasil. São Paulo: Cia. Melhoramento de S. Paulo, 1922; Almanaque Laemmert, 18441889. 
TABELA 4 - Nobreza e gabinetes ministeriais (1831-1848)

\begin{tabular}{|c|c|c|c|c|}
\hline Gabinetes & Período & $\mathrm{N}^{\mathrm{o}}$ de pastas & $\mathrm{N}^{\mathrm{o}}$ de pastas controladas por nobres & $\%$ de nobres \\
\hline \multicolumn{5}{|c|}{ Regência Provisória } \\
\hline $1^{0}$ & 1831 & 06 & 0 & $0,0 \%$ \\
\hline \multicolumn{5}{|c|}{ Regência Permanente } \\
\hline $1^{0}$ & 1831 & 06 & 02 & $0,0 \%$ \\
\hline $2^{0}$ & 1832 & 06 & 04 & $33,3 \%$ \\
\hline $3^{0}$ & 1832 & 06 & 06 & $66,6 \%$ \\
\hline $4^{0}$ & 1835 & 06 & 05 & $83,3 \%$ \\
\hline \multicolumn{5}{|c|}{ Regência Feijó } \\
\hline $1^{0}$ & 1835 & 06 & 03 & $50 \%$ \\
\hline $2^{0}$ & 1836 & 06 & 02 & $33,3 \%$ \\
\hline $3^{0}$ & 1836 & 06 & 03 & $50 \%$ \\
\hline $4^{0}$ & 1837 & 06 & 04 & $66,6 \%$ \\
\hline \multicolumn{5}{|c|}{ Regência de Pedro de Araújo Lima } \\
\hline $1^{0}$ & 1837 & 06 & 03 & $50 \%$ \\
\hline $2^{0}$ & 1839 & 06 & 00 & $0,0 \%$ \\
\hline $3^{0}$ & 1839 & 06 & 03 & $50 \%$ \\
\hline $4^{0}$ & 1840 & 06 & 04 & $66,6 \%$ \\
\hline
\end{tabular}


REVISTA ESBOÇOS Volume 17, № 23, pp. 187-221 - UFSC

TABELA 4 - Nobreza e gabinetes ministeriais (1831-1848) (cont.)

\begin{tabular}{|c|c|c|c|c|}
\hline Gabinetes & Período & $\mathrm{N}^{\mathrm{o}}$ de pastas & $\mathrm{N}^{\mathrm{o}}$ de pastas controladas por nobres & $\%$ de nobres \\
\hline \multicolumn{5}{|c|}{ Segundo Reinado } \\
\hline $1^{0}$ & 1840 & 06 & 04 & $66,6 \%$ \\
\hline $2^{0}$ & 1841 & 06 & 06 & $100 \%$ \\
\hline $3^{0}$ & 1843 & 06 & 04 & $66,6 \%$ \\
\hline $4^{0}$ & 1844 & 06 & 04 & $66,6 \%$ \\
\hline $5^{0}$ & 1845 & 06 & 06 & $100 \%$ \\
\hline $6^{0}$ & 1846 & 06 & 04 & $66,6 \%$ \\
\hline $7^{0}$ & 1847 & 06 & 04 & $66,6 \%$ \\
\hline $8^{0}$ & 1848 & 06 & 04 & $66,6 \%$ \\
\hline $9^{0}$ & 1848 & 06 & 00 & $0 \%$ \\
\hline $10^{0}$ & 1848 & 06 & 03 & $50 \%$ \\
\hline
\end{tabular}

Fonte: Barão de Javari. Organizações e Programas Ministeriais. Rio de Janeiro: Departamento de Imprensa Nacional, 1979 , p.33-105. 
TABELA 5 - Presença de nobres nos Gabinetes (1831-1848).

\begin{tabular}{|c|c|c|c|c|c|c|c|}
\hline $\begin{array}{c}\text { Pastas } \\
\text { ministeriais }\end{array}$ & $\begin{array}{c}\text { Total de } \\
\text { Gabinetes } \\
(1831-1848)\end{array}$ & $\begin{array}{c}\text { Total de } \\
\text { ministros } \\
(1831-1848)\end{array}$ & $\begin{array}{c}\text { Ministérios } \\
\text { sem } \\
\text { áulicos }\end{array}$ & $\begin{array}{c}\text { Total de } \\
\text { ministros } \\
\text { não áulicos }\end{array}$ & $\begin{array}{c}\text { Ministérios } \\
\text { com } \\
\text { áulicos }\end{array}$ & $\begin{array}{l}\text { Total de } \\
\text { ministros } \\
\text { áulicos }\end{array}$ & $\%$ \\
\hline Fazenda & 22 & 32 & 9 & 16 & 13 & 16 & $50 \%$ \\
\hline Império & 22 & 33 & 7 & 13 & 15 & 20 & $60,6 \%$ \\
\hline Justiça & 22 & 34 & 7 & 10 & 15 & 24 & $70,5 \%$ \\
\hline Estrangeiros & 22 & 29 & 4 & 6 & 18 & 23 & $79,3 \%$ \\
\hline Guerra & 22 & 28 & 9 & 13 & 13 & 15 & $53,5 \%$ \\
\hline Marinha & 22 & 33 & 10 & 18 & 12 & 15 & $45,4 \%$ \\
\hline Total & $*$ & 189 & $*$ & 76 & $*$ & 113 & $59,7 \%$ \\
\hline
\end{tabular}

Fontes: Barão de Javari. Organizações e Programas Ministeriais. Rio de Janeiro: Departamento de Imprensa Nacional, 1962, p.104 e 113; Tavares de Lyra. Instituições Políticas do Império. Brasília: Senado Federal, 1978; Max Fleiuss. História Administrativa do Brasil. São Paulo: Cia. Melhoramento de S. Paulo, 1922. 